Article

\title{
Preterm Delivery: Role of Zinc
}

\author{
Masuda Sultana ${ }^{1}$, Nasim Jahan ${ }^{2}$, Nayma Sultana ${ }^{3}$, Shamshad Begum Quraishi' ${ }^{4}$, Tasrina Rabeya \\ Chowdhury
}

\begin{abstract}
Background: Preterm delivery is a very challenging obstetric complication in Bangladesh. Reduced serum zinc (Zn) concentration of the pregnant mother may have some role in causing preterm delivery. Objectives: To measure serum zinc level in preterm delivery mother and their respective neonates to observe their status. Methods: This cross sectional study was carried out in the Department of Physiology, Sir Salimullah Medical College, Mitford Hospital, Dhaka, during the period of $1^{\text {st }}$ January to $31^{\text {st }}$ December 2009. A total 136 subjects were included in this study, of whom 27 were full term delivery mother with their respective neonates (group B), treated as control group and another 27 were preterm delivery mothers with their respective neonates (group C), treated as study group. Age ranged of preterm and full term mother were from 20-40 years. Again, 28 non pregnant women with age range from 20-30 years were taken as reference value (groupa A). Statistical analysis was done by using appropriate method as applicable. Results: Mean serum zinc level was significantly $(\mathrm{p}<0.001)$ lower in preterm mother in comparison to that of full term mother and also in preterm neonates than that of full term neonates. Serum total protein and albumin were significantly $(\mathrm{p}<0.001)$ lower in preterm mother than those of full term mother and also in preterm neonates than those of their respective mothers and full term neonates. Again, maternal serum zinc level showed positive correlation with birth weight of neonates and also with zinc concentration of neonatal blood. Conclusions: The present study revealed a lower level of serum zinc in pre-term delivery mother and their neonates. These hypozincemia may be responsible for low birth weight of the fetus.
\end{abstract}

Key Words: Zinc , preterm

J Bangladesh Soc Physiol. 2010 June; 5(1): 27-33 For author affiliations, see end of text.

http://www.banglajol.info/index.php/JBSP

\section{Introduction}

$\mathbf{P}$ reterm delivery can be defined as the onset of labor prior to 37 weeks of gestation ${ }^{1}$. Incidence of preterm labor is 23.3\% in India ${ }^{2}$ and in Bangladesh 16.7\% ${ }^{3}$. Nutritional deficiencies such as deficiency of proteins, vitamins and some minerals especially zinc (Zn) may be responsible for preterm delivery particularly in the developing countries ${ }^{2}$. Trace elements needed in minute quantities are essential for development and normal function of the body as well as for healthy fetal outcome.
Zinc plays a definitive role in this regard ${ }^{4}$. Deficiency of this micronutrient causes a number of maternal and fetal complications during pregnancy and delivery ${ }^{5,6}$.

The serum Zn concentration may decrease during pregnancy mainly due to hemodilution, decreased availability of $\mathrm{Zn}$ binding protein, hormonal changes during pregnancy and decreased binding affinity to albumin ${ }^{7,8}$. Serum $\mathrm{Zn}$ concentration begins to decline in early 
pregnancy and continues till term where it is about 35\% lower than that in the non pregnant female . $^{9}$.

Low maternal zinc status during pregnancy causes 3.5 to 7 fold increased risk for premature rupture of amniotic membrane and induce preterm labor $^{10}$. Again, a low intake of $\mathrm{Zn}$ during pregnancy may cause increased risk of low birth weight as well as preterm delivery ${ }^{11,12}$

Low maternal serum Zn concentration during pregnancy may be associated with pregnancy induced hypertension, abruptio placentae, inefficient uterine contraction, prolonged or nonprogressive labor and maternal haemorrhge and infections ${ }^{10,11}$. Again, severe maternal $\mathrm{Zn}$ deficiency may cause spontaneous abortion, congenital abnormalities such as anencephaly, hydrochephaly and stressful parturition ${ }^{13}$.

Preterm delivery is a challenging obstetric problem in our country. Deficiency of Zn may have some role on this regard. Some study has been done regarding this matter in abroad ${ }^{12,14,15}$. But no published data is available in our country on this aspect. Therefore the present study has been undertaken to measure serum zinc level in preterm delivery mother and their respective neonates to observe their status.

\section{Methods}

The present cross sectional study was carried out in the Department of Physiology, Sir Salimullah Medical College, Mitford Hospital, Dhaka, during the period of $1^{\text {st }}$ January 2009 to $31^{\text {st }}$ December 2009. A total number of 136 subjects were included in this study, and all of them belonged to lower socioeconomic status. Among them 54 were full term delivery mother with their respective neonates (group B), treated as control group. Of them 27 were full term mother $\left(B_{1}\right)$ and 27 were neonates of the respective mother $\left(B_{2}\right)$. Again, another 54 were preterm delivery mothers with their respective neonates (group C), and treated as study group. Of them 27 were preterm mother $\left(C_{1}\right)$ and 27 were neonates of the respective mother $\left(C_{2}\right)$. Age ranged of preterm and full term mother were from 20-40 years. Again, 28 non pregnant women with age range from 20-30 years were taken as reference value (group A). Protocol of this study was approved by the ethical committee of SSMC. Subjects having history of any microbial and metabolic diseases were excluded from the study. All the pregnant mothers were collected from emergency labor ward in Sir Salimullah Medical College, Mitford Hospital and non-pregnant women were selected from personal contact. After selection of the subjects, the objectives and benefits of the study were explained and written informed consent was taken from the subjects. All ethical norms were maintained. Institutional permission was taken from the Director of the Hospital. Detail personal, dietary, medical, family, socio economic, occupational histories were taken and a thorough clinical examination were done and all information was recorded in a standard prefixed questionnaire. With all aseptic precautions $5 \mathrm{ml}$ of maternal blood were drawn from medial cubital vein by disposable syringe and $5 \mathrm{ml}$ of neonatal blood were collected from placental end of cord immediately after delivery. Blood was centrifuged at 3000 rpm for 20 minutes. After that supernatant serum was collected in labeled eppendroff tube and from it $1 \mathrm{ml}$ of serum was transferred in a plain glass test tube for estimation of serum total protein and albumin by standard laboratory technique ${ }^{16}$ in the laboratory of Physiology Department, SSMC, Dhaka. Another $1 \mathrm{ml}$ was taken in deionized tube for estimation of serum zinc level by spectrophotometric method ${ }^{17}$ in the laboratory of Atomic Energy Commission. The statistical analysis was done by Independent-samples t test and Pearson's correlation by using SPSS, Version-15.

\section{Results}

Antropometric data of the subjects are presented in Table I. This table shows that mean height $(\mathrm{p}<0.01)$, weight $(\mathrm{p}<0.001)$ and BMI $(\mathrm{p}<0.001)$ were significantly lower in group $C_{1}$ in comparison to that group $\mathrm{B}_{1}$. In the present study

J Bangladesh Soc Physiol. 2010 June; 5(1): 27-33 
Preterm Delivery: Role of Zinc

Article

Table I: Mean \pm SD Age, Height, Weight and BMI in different groups ( $\mathrm{n}=136$ )

\begin{tabular}{lccccc}
\hline Groups & $\mathrm{n}$ & Age (year) & Height (meter) & Weight $(\mathrm{kg})$ & BMI $\left(\mathrm{kg} / \mathrm{m}^{2}\right)$ \\
\hline $\mathrm{A}$ & 28 & $20.50 \pm 0.64$ & $154.76 \pm 2.07$ & $57.50 \pm 2.59$ & $24.00 \pm 0.65$ \\
$\mathrm{~B}_{1}$ & 27 & $24.74 \pm 3.34$ & $156.63 \pm 2.17$ & $62.07 \pm 1.92$ & $25.30 \pm 0.63$ \\
$\mathrm{~B}_{2}$ & 27 & - & - & $3.03 \pm 0.31$ & - \\
$\mathrm{C}_{1}$ & 27 & $23.37 \pm 3.98$ & $154.85 \pm 2.46$ & $56.22 \pm 4.29$ & $23.42 \pm 1.36$ \\
$\mathrm{C}_{2}$ & 27 & - & - & $2.22 \pm 0.25$ & - \\
\hline
\end{tabular}

Statistical analysis:

\begin{tabular}{lcccc}
\hline \multicolumn{5}{c}{ p value } \\
\hline $\mathrm{B}_{1}$ vs C $_{1}$ & $0.176^{n \mathrm{~ns}}$ & $0.007^{* *}$ & $0.000^{* * *}$ & $0.000^{* * *}$ \\
$\mathrm{~B}_{2}$ vs $\mathrm{C}_{2}$ & - & - & $0.000^{* * *}$ & - \\
\hline
\end{tabular}

Group A = Apparently healthy non-pregnant women (Baseline control)

Group B (Control)

$\mathrm{B}_{1}=$ Full term mother

$\mathrm{B}_{2}=$ Full term neonates of the respective mother

Group C (Study)

$\mathrm{C}_{1}=$ Preterm mother

$\mathrm{C}_{2}=$ Preterm neonates of the respective mother

$\mathrm{n}=$ Total number of subjects, $\mathrm{ns}=$ not significant, ${ }^{* * *}=$ significant at $\mathrm{p}<0.001, * *=$ significant $\mathrm{at} \mathrm{p}<0.01$

birth weight of group $\mathrm{C}_{2}$ was significantly $(p<0.001)$ lower than that of group $B_{2}$. Whereas, the weights of full term neonates were within normal reference value.

Mean serum zinc level was significantly $(\mathrm{p}<0.001)$ lower in group $\mathrm{C}_{1}$ in comparison to that of group $B_{1}$ and also in group $C_{2}$ than that of group $B_{2}$. Again, serum Zn level was significantly $(\mathrm{p}<0.001)$ higher in $\mathrm{B}_{2}$ in comparison to that of $\mathrm{B}_{1}$. No statistically significant difference of this level was observed between $\mathrm{C}_{1}$ vs $_{2}$ (Table II).

Mean serum total protein and albumin were significantly $(\mathrm{p}<0.001)$ lower in group $\mathrm{C}_{1}$ than those of group $\mathrm{B}_{1}$. Again, these values were significantly $(\mathrm{p}<0.001)$ lower in group $\mathrm{C}_{2}$ in comparison to those of group $\mathrm{B}_{2}$. On the other hand, mean serum globulin levels were almost similar and no statistically significant difference were observed between group $B_{1}$ vs $C_{1}, B_{1}$ vs $\mathrm{B}_{2}$ and $\mathrm{B}_{2}$ vs $\mathrm{C}_{2}$.
Table II: Mean \pm SD Serum zinc (Zn) levels in different groups ( $\mathrm{n}=136)$

\begin{tabular}{llc}
\hline Groups & $\mathrm{n}$ & $\mathrm{Zn}(\mu \mathrm{g} / \mathrm{dl})$ \\
\hline $\mathrm{A}$ & 28 & $74.32 \pm 9.13$ \\
$\mathrm{~B}_{1}$ & 27 & $62.70 \pm 7.18$ \\
$\mathrm{~B}_{2}$ & 27 & $74.90 \pm 10.89$ \\
$\mathrm{C}_{1}$ & 27 & $33.30 \pm 11.00$ \\
$\mathrm{C}_{2}$ & 27 & $31.74 \pm 6.21$ \\
\hline
\end{tabular}

Statistical analysis:

\begin{tabular}{lc}
\hline & $\mathrm{p}$ value \\
\hline $\mathrm{B}_{1}$ vs C $_{1}$ & $0.000^{* * *}$ \\
$\mathrm{~B}_{1}$ vs $_{2}$ & $0.000^{* * *}$ \\
$\mathrm{C}_{1}$ vs C $_{2}$ & $0.525^{\text {ns }}$ \\
$\mathrm{B}_{2}$ vs C $_{2}$ & $0.000^{* * *}$ \\
\hline
\end{tabular}

Group A = Apparently healthy non-pregnant women (Baseline control)

Group B (Control):

$\mathrm{B}_{1}=$ Full term mother

$\mathrm{B}_{2}=$ Full term neonates of the respective mother Group C (Study):

$\mathrm{C}_{1}=$ Preterm mother

$\mathrm{C}_{2}=$ Preterm neonates of the respective mother . $\mathrm{n}=$ Total number of subjects

ns $=$ not significant $\quad * * *=$ significant at $\mathrm{p}<0.001$ 
Table III: Mean \pm SD Serum total protein, albumin, globulin and albumin/globulin ratio in different groups $(\mathrm{n}=136)$

\begin{tabular}{lccccc}
\hline Groups & $\mathrm{n}$ & $\begin{array}{c}\text { Total Protein } \\
(\mathrm{g} / \mathrm{dl})\end{array}$ & $\begin{array}{c}\text { Albumin } \\
(\mathrm{g} / \mathrm{dl})\end{array}$ & $\begin{array}{c}\text { Globulin } \\
(\mathrm{g} / \mathrm{dl})\end{array}$ & $\begin{array}{c}\mathrm{A} / \mathrm{G} \\
\text { ratio }\end{array}$ \\
\hline $\mathrm{A}$ & 28 & $7.18 \pm 0.91$ & $4.79 \pm 0.88$ & $2.39 \pm 0.75$ & $2.23 \pm 0.87$ \\
$\mathrm{~B}_{1}$ & 27 & $7.40 \pm 1.52$ & $4.81 \pm 1.14$ & $2.58 \pm 1.13$ & $2.26 \pm 1.16$ \\
$\mathrm{~B}_{2}$ & 27 & $6.02 \pm 1.50$ & $4.10 \pm 1.14$ & $1.93 \pm 0.75$ & $2.38 \pm 1.11$ \\
$\mathrm{C}_{1}$ & 27 & $5.35 \pm 1.21$ & $3.10 \pm 0.98$ & $2.25 \pm 0.63$ & $1.50 \pm 0.69$ \\
$\mathrm{C}_{2}$ & 27 & $3.76 \pm 0.62$ & $1.98 \pm 0.50$ & $1.78 \pm 0.58$ & $1.50 \pm 1.78$ \\
\hline Statistical analysis & & & & \\
\hline & & & & \\
\hline $\mathrm{B}_{1}$ vs C $_{1}$ & $0.000^{* * *}$ & $0.000^{* * *}$ & $0.272^{\mathrm{ns}}$ & $0.066^{\mathrm{ns}}$ & \\
$\mathrm{B}_{1}$ vs $_{2}$ & $0.002^{* *}$ & $0.030^{*}$ & $0.064^{\mathrm{ns}}$ & $0.932^{\mathrm{ns}}$ & \\
$\mathrm{C}_{1}$ vs $_{2}$ & $0.000^{* * *}$ & $0.000^{* * *}$ & $0.006^{* *}$ & $0.996^{\mathrm{ns}}$ & \\
$\mathrm{B}_{2}$ vs C $_{2}$ & $0.000^{* * *}$ & $0.000^{* * *}$ & $0.543^{\mathrm{ns}}$ & $0.040^{*}$ & \\
\hline
\end{tabular}

Group A = Apparently healthy non-pregnant women (Baseline control)

Group B (Control)

$\mathrm{B}_{1}=$ Healthy full term delivery mother

$\mathrm{B}_{2}=$ Full term neonates of the respective mother

Group C (Study)

$\mathrm{C}_{1}=$ Preterm delivery mother

$\mathrm{C}_{2}=$ Preterm neonates of the respective mother

$\mathrm{n}=$ Total number of subjects. $\mathrm{ns}=$ not significant

$* * *=$ significant at $\mathrm{p}<0.001, * *=$ significant at $\mathrm{p}<0.01$

$*=$ significant at $\mathrm{p}<0.05$

Again, correlations of maternal serum zinc concentration with birth weight of their neonates and with $\mathrm{Zn}$ concentration of neonatal blood are presented in figure 1 and 2. Maternal serum zinc level showed positive correlation with birth weight in group $B(r=0.025, p>0.05)$ and group C $(r=0.514, \mathrm{p}<0.05)$ which was statistically significant only in group $C$. On the other hand, maternal serum zinc level showed positive correlation with neonatal blood in group $B(r=0.108 p>0.05)$ and group $C(r=0.257$, $\mathrm{p}>0.05)$.

J Bangladesh Soc Physiol. 2010 June; 5(1): 27-33 
Preterm Delivery: Role of Zinc

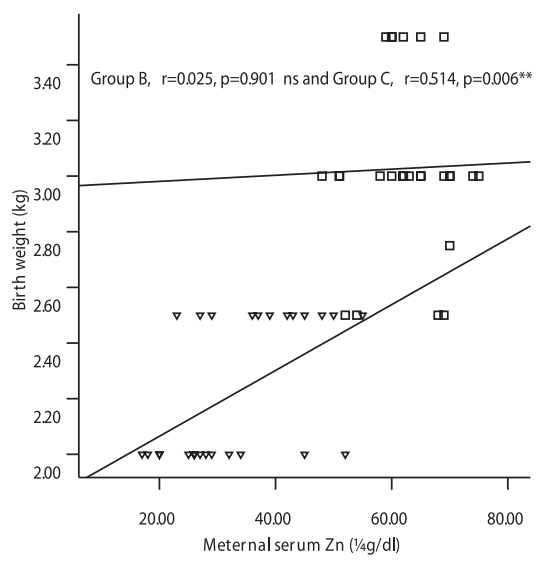

Group B: (Control)

Group $\mathrm{B}_{1}=$ Healthy full term delivery mother

Group $B_{2}=$ Full term neonates of the respective mother

Group C: (Study)

Group $\mathrm{C}_{1}=$ Preterm delivery mother

Group $\mathrm{C}_{2}=$ Preterm neonates of the respective mother

ns= not significant

$* *=$ significant at $\mathrm{p}<0.01$

Figure 1: Correlation of maternal serum zinc (Zn) concentration with the birth weight of their neonates in group B ( $n=54)$ and group C $(n=54)$

\section{Discussion}

In this study, serum zinc deficiencies have been found both in preterm delivery mother and their neonates. Again, low birth weights have been found in this group of neonates. These findings are in agreement with those of some other researchers ${ }^{12,18}$. Pregnant women in developing countries consume diets with a lower quantity of protein, minerals and vitamins ${ }^{19}$. An inadequate dietary intake before and during pregnancy is high risk factor both for mother and fetus, which may be responsible for preterm delivery as well as for low birth weight of the neonates ${ }^{6}$.

However, lower level of serum $\mathrm{Zn}$ in preterm mother might be due to its low dietary intake, increased body demand, malabsorption,
Article

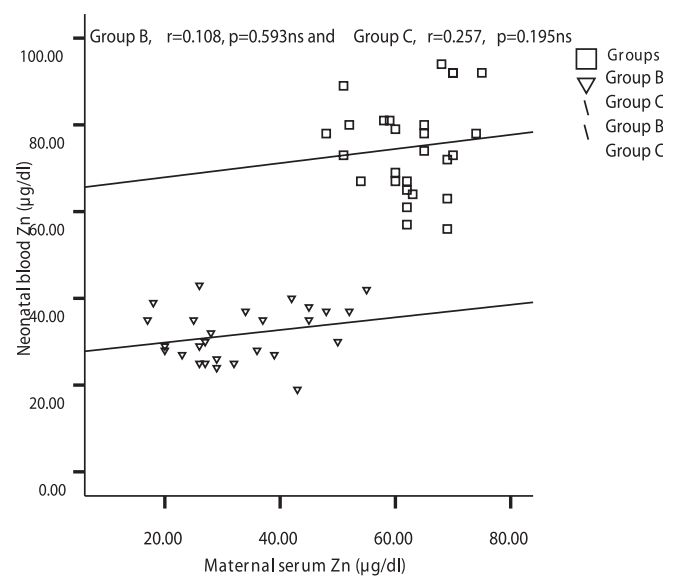

Group B: (Control)

Group $B_{1}=$ Healthy full term delivery mother

Group $B_{2}=$ Full term neonates of the respective mother

Group C: (Study)

Group $\mathrm{C}_{1}=$ Preterm delivery mother

Group $C_{2}=$ Preterm neonates of the respective mother

ns= not significant

Figure 2: Correlation of maternal serum zinc (Zn) concentration with zinc concentration of neonatal blood in group B $(n=54)$ and group C $(n=54)$

increased urinary excretion and impaired utilization $^{19,20}$. Grain products containing dietary fiber and phytate decrease its absorption ${ }^{21}$. Again, increased urinary excretion due to decreased availability of binding protein causes lower serum $\mathrm{Zn}$ level ${ }^{22}$ It has also been suggested that low serum Zn concentration during pregnancy might be due to physiological hemodilution, decreased in Zn binding capacity, increase transfer of $\mathrm{Zn}$ from the mother to the fetus ${ }^{7,8,12}$. In addition to fetal accumulation, $\mathrm{Zn}$ is also deposited in placenta and amniotic fluid, leading to the lowering of maternal serum $\mathrm{Zn}^{23}$. Again, hypozincemia in preterm neonates might be due to increased demand of this micronutrient for fetal growth, erythropoiesis and immaturity of the liver to synthesize $\mathrm{Zn}$ binding protein ${ }^{1,12}$. 
It has been suggested that Zn deficiency may lead to defective function of estrogen which may impair uterine contractions, cervical dilation and amniotic fluid integrity. Furthermore, low maternal Zn status during pregnancy may cause premature rupture of amniotic membrane which in turn induces preterm labor ${ }^{10,11}$. Again, several investigators demonstrated the relationship between low serum $\mathrm{Zn}$ concentration during pregnancy and small for gestational age $\mathrm{e}^{11,12}$.

In the present study, hypozincemia was observed in preterm delivery mother is most likely due to decreased levels of binding protein as the observed levels of them were lower. In addition, poor socio-economic status of the study subjects also indicates inadequate food intake especially low dietary protein. Again, low birth weight of preterm neonates in this study may be due to their hypozincemia, as evidenced by their measured values in cord blood. This hypozincemia of preterm neonates of present study may be due to low maternal serum $\mathrm{Zn}$ concentration, as evidenced by the positive correlation of maternal serum Zn concentration with that of neonatal blood have been found in this study. Again, in this study positive correlation of maternal zinc concentration with birth weight of neonates are also suggestive of necessity of this micronutrient for healthy outcome.

\section{Conclusion}

This study concludes that, hypozincemia may be present in preterm mother and their neonates. This study also tried to prove the effects of low serum Zn levels on fetal outcome, as supported by their low birth weight. So, along with zinc supplementation, protein enrich diet is also necessary for some zinc deficient pregnant women to prevent preterm delivery and for healthy fetal outcome.

\section{Acknowledgement}

Authors of this study are thankful to the authority of Atomic Energy Commission for the cooperation regarding laboratory facility they provided. I would also express my sincere thanks to the Director of Medical Education for the valuable fund which was enormously supported for completing the research work.

\section{Author Affiliations}

*1. Masuda Sultana, Assistant Professor of Physiology, Dhaka Community Medical College, Dhaka.Email;dr_masuda30@yahoo.com

2. Professor Nasim Jahan, Professor and Head, Department of Physiology, Sir Salimullah Medical College SSMC, Dhaka, Bangladesh.

3. Nayma Sultana, Assistant Professor, Department of Physiology Sir Salimullah Medical College (SSMC), Dhaka, Bangladesh..E mail:nayma_sultana@ yahoo.com

4. Shamshad Begum Quraishi, Principle Scientific Officer, Chemistry Division, Atomic Energy Center, Dhaka, Bangladesh.

5. Tasrina Rabeya Chowdhury, Scientific Officer, Chemistry Division, Atomic Energy Center, Dhaka.

*For correspondence

\section{References}

1. Artel R, Burgeson R, Fernandez FJ, Hobel CJ. Fetal And Maternal Copper Levels In Patients At Term With And Without Premature Rupture Of Membranes. Obstet Gynecol 1979;53(5):608-610..

2. Uma S, Nisha S, Shikha S . A Prospective Analysis Of Etiology And Outcome of Preterm Labor. J Obstet Gynecol Ind. 2007; 57(1): 48-52.

3. Percentage Distribution Of Mothers Who Had Reported Problems During And After Pregnancy. Health and Demographic survey, September 1999 to August 2000 .Statistical Pocket book of Bangladesh 2008. Dhaka: Bangladesh Bureau of Statistics; 2009. 381p.

4. Pathak P, Kapil U. Role Of Trace Elements Zinc, Copper And Magnesium During Pregnancy And Its Outcome. Ind J Ped. 2004; 71(11): 1003-5.

5. Hurly LS. Maternal Catabolism And Fetal Zinc Status. Nutr Res. 1985 ;1(S):300-05.

6. Bro S, Berendtsen H, Norgaard J, Host A, Jorgensen PJ. Serum Zinc And Copper Concentrations In Maternal And Umbilical Cord Blood. Relation To Course And Outcome of Pregnancy. Sca J Clin Lab Invest. 1988; 48: 805-11.

J Bangladesh Soc Physiol. 2010 June; 5(1): 27-33 
7. Jameson S. Effects Of Zinc Deficiency In Human Reproduction. Ac Med Scand. 1976; $\quad$ 593: 5-66.

8. Perveen S, Altaf W, Vohra N, Bautista ML, Harper RG, Wapnir RA. Effect of Gestational Age On Cord Blood Plasma Copper, Zinc, Magnesium And Albumin. Early Hum Dev. 2002; 69:15-23.

9. Zimmerman, Dunhan, Nochimson, Kaplan, Clive, Kunkel. Zinc Transport In Pregnancy. Am J Obstet Gynaecol. 1984; 149: 523-29.

10. Sikorski R, Juszkiewicz T, Paszkowski T. Zinc Status In Women With Premature Rupture Of Membranes At Term. Obstet Gynecol. 1990; 76(4):675-77.

11. Scholl TO, Heliger ML, Scholl JI, Fischer RL, Khoo C. Low Zinc Intake During Pregnancy: Its Association With Preterm And Very Preterm Delivery. Am J Epi.1993;137(10): 1115-24.

12. Caulfield LE, Zavaleta N., Shankar AH, Merialdi M. Potential Contribution Of Maternal Zinc Supplementation During Pregnancy To Maternal And Child Survival. Am J Clin Nutr. 1998; 68(Suppl): 499S-508S.

13. Hambidge KM, Neldner KH, Walravens PA, Zinc Acrodermatitis Entero Pathica And Congenital Malformations. Lancet. 1975; 8: 577-78.

14. Atinmo T, Mbofung C, Osinusi BO. Relationship of zinc and copper concentrations in maternal and cord blood and birth weight. J Gynaecol Obstet. 1980; 452-454.
15. Shaw JCL. Trace Elements In The Fetus And Young Infant. Am J Dis Child. 1980;134: 74-81.

16. Weichselbaum TE. Am J Clin Path $1946 ; 16: 40$.

17. Smith JC, Butrimovitz, GP, Purdy WC. Direct Measurement Of Zinc And Copper In Plasma By Atomic Absorption Spectroscopy. Clin Chem. 1979; 25(8):1487-1491.

18. Tamura T, Goldenberg RL, Johnston KE, Dubard M. Maternal plasma zinc concentrations and pregnancy outcome. Am Soci Clin Nutr. 2000; 71: 109-113.

19. Mahan LK, Escott- Stump S. Nutrition during pregnancy and lactation. In: Krause's. Food, nutrition and diet therapy. Philadelphia:WB Saunders company;2004. P.183-9.

20. Jeswani RM, Vani SN. A Study Of Serum Zinc Levels In Cord Blood Of Neonates And Their Mothers. Ind J Ped. 1991; 58: 683-7.

21. Ward RJ, Abraham R, Mcfadyen IR, Haines AD, North WRS, Patel M, Bhatt RV. Assessment Of Trace Metal Intake And Status In A Gujerati Pregnant Asian Population And Their Influence On The Outcome Of Pregnancy. Br J Obstet Gynecol. 1988; 95: 676- 82.

22. Curthbertson PD, Fell SG, Smith MC, Tilstone JW. Effects Of Severity, Nutrition And Environmental Temperature On Protein, Pottassium, Zinc And Creatine. Br J Surg Soc.1972; 59:925-31.

23. Swanson CA, King JC. Reduced Serum Zinc Concentration During Pregnancy. Obstet Gynecol. 1983; 62(3): 313-18. 